\title{
Age of menarche in girls with sight organ diseases
}

\author{
Wioleta Umławska \\ Department of Anthropology, University of Wrocław, Kuźnicza 35 \\ 50-138 Wrocław, Poland, E-mail: wilota@antropo.uni.wroc.pl
}

\begin{abstract}
The paper attempts to clarify the reasons for sooner pubescence of girls with sight defects than that of their normally seeing peers. The age of menarche was considered depending on the degree of the sight impairment and the disease etiology as well as some selected factors of the socio-economic environment in the examined girls' families.
\end{abstract}

KEY WORDS sight impairment girls, menarche, pubescence

Prz. Antropol. - Anthropol. Rev. (2000), vol. 63, pp. 85-93, Tables 9. ISBN 83-86969-60-1, ISSN 0033-2003

Few investigations concerning the pubescence age of girls with sight defects have been published in the anthropological and medical literature [ZACHARIAS \& WURTMAN 1964; BUDAY 1981; LUCZAK 1992; BUDAY \& KAPOSI 1995]. Still, the authors' reports suggest sooner pubescence of these girls than of their normally seeing peers; besides, some of them postulate an important role of the pineal body in this process.

The aim of this research is to specify the pubescence age of girls with the sight organ diseases depending on the degree of the sight impairment, the defect etiology and some selected socio-economic aspects of the examined girls' families.

\section{Materials and methods}

The material consists of anthropometric data and questionnaire information gathered from 130 girls aged from 6 to 20 (Table 1). The interrogated girls were pupils of two Educational and Boarding Centers for Blind Children - in Wrocław and in Kraków. The material was gathered in the autumn of 1994 and 1995. The research included only teenagers and children with amblyopia, and blind ones, with no disorders of mental development.

The interviews provided the information about the age of the questioned individuals, their origin (big city - over 100,000 inhabitants, small town, village), their parents' education (university, secondary, vocational, elementary), the number of children in the family (including the interviewee), and also possible abnormalities in their families (broken-up or neglected families, and parents' alcoholism). The examined girls were asked about the age of their menarche (limited quantity of material did 
Table 1. Age distribution of examined girls (years)

\begin{tabular}{lc}
\hline Age & $N$ \\
\hline $6-8$ & 7 \\
$8-10$ & 9 \\
$10-12$ & 19 \\
$12-14$ & 20 \\
$14-16$ & 25 \\
$16-18$ & 36 \\
$18-20$ & 14 \\
\hline
\end{tabular}

not allow for applying the status quo method). The information concerning the basis and degree of sight defect progression was obtained from medical cards of schoolgirls of both centers, the cards being supplied by doctors.

Depending on the degree of the sight impairment, two categories of the examined girls were distinguished: those with amblyopia and blind ones. Considering the disease etiology, the schoolgirls were divided into 3 groups. The first group included girls with hereditary defects and syndromes, the second one - with acquired innate defects, and the last one with defects acquired after birth, i.e., injuries, neoplasm changes or infants' retinopathy.

The frame of reference consisted of data gathered and elaborated by employees of the Department of Anthropology PAN in Wrockaw within the years of 1987/88 (so-called the Fourth Anthropological Examination) for children and teenagers of Wrocław [HULANICKA et al. 1990]. For the statistical analysis of data $t$-Student test, variance analysis and chi-square test were employed.

\section{Results and discussion}

The age of menarche in girls with sight deficit was determined with a retrospective method. 77 girls provided a detailed age of the menarche; 73 answers were taken into account for the analysis, and the answers of 4 girls with extreme menarche age (9.00, 9.25, 9.75 and 17.42 years of age) were rejected. The average age of menarche of girls with sight defects (Table 2) is almost 5 months sooner than the age obtained for female inhabitants of Wrocław in 1987, amounting to 13.16 years of age [HULANICKA et al. 1990].

Table 2. Characteristics of the age of menarche for all the examined girls

\begin{tabular}{cccccc}
\hline $\bar{x}$ & $M e$ & $N$ & $S D$ & $\min$ & $\max$ \\
\hline $12.75 \pm 0.15$ & 12.67 & 73 & 1.27 & 9.83 & 15.50 \\
\hline
\end{tabular}

Specifying the age of menarche with the retrospective method (the only method possible to employ here) allowed for conducting it on material excluding girls who have not menstruated yet (21 girls between 10 and 13 year of age and after 13 year of age). For this reason, the median of the age distribution of the menarche was calculated. Since the median value turned out to be very close to the arithmetic mean $(M e=12,67 ; \overline{\mathrm{x}}=12,75)$, one can assume that there has been not any significant change of the mean value.

The age of menarche was differentiated depending on the degree of the sight impairment. Blind girls have their first menstruation almost 6 months sooner than girls with amblyopia (Table 3). Yet, considering the small number of blind girls, this difference did not reach the statistical significance level. However, the etiology of the sight organ chronic disease (despite its small number), significantly differentiates the age of menarche (Table 4). Girls with acquired sight defects were the first to enter the pubescence period, and girls with innate hereditary ones - reach puberty as the last 
Table 3. Age of menarche depending on degree of sight impairment

\begin{tabular}{lccc}
\hline Girls & $\bar{x}$ & $N$ & $S D$ \\
\hline with amblyopia & $12.87 \pm 0.17$ & 55 & 1.29 \\
blind & $12.39 \pm 0.28$ & 18 & 1.18 \\
\hline $\begin{array}{l}\text { Difference between } \\
p>0.05)\end{array}$ & categories insignificant $(t=1.41$
\end{tabular}

Table 4. Age of menarche depending on etiology of sight organ chronic disease

\begin{tabular}{lccc}
\hline Kind of defect & $\overline{\mathrm{x}}$ & $N$ & $S D$ \\
\hline innate hereditary & $13.25^{\star} \pm 0.31$ & 17 & 1.29 \\
acquired innate & $12.81 \pm 0.19$ & 40 & 1.22 \\
acquired postnatal & $12.08^{\star} \pm 0.29$ & 16 & 1.15 \\
\hline
\end{tabular}

* Significant difference between categories $(F=3.91$; $p<0.05$ )

ones. The difference between the extreme groups amounted to as many as 14 months. It is worth highlighting that $80 \%$ of the examined girls with sight defects acquired after birth are prematurely born girls, and these are characterized by sooner puberty age in relation to all the remaining girls (Table 5).

Table 5. Age of menarche of girls born in due time and before term

\begin{tabular}{lccc}
\hline Girls born & $\overline{\mathrm{x}}$ & $N$ & $S D$ \\
\hline in due time & $12.92 \pm 0.16$ & 60 & 1.22 \\
before term & $11.97 \pm 0.34$ & 13 & 1.24 \\
\hline
\end{tabular}

Significant difference between categories $(t=2.56$; $p<0.05$ )

The age of menarche of examined girls was also evaluated depending on the environment variables. Factors determining the socio-economic status of the examined girls' families have a considerable influence on the beginning of pubescence. It is well known that the urbanization is a factor determining the age of menarche to a large extent; girls coming from big cities mature the soonest, and those coming from the villages - the latest. In the examined materials, the difference of puberty age between female inhabitants of big cities and villages is nearly 10 months, while between those coming from small towns and villages approximately 2 months (Table 6).

Table 6. Age at menarche of examined girls depending on urban factor

\begin{tabular}{lccc}
\hline Place of origin & $\overline{\mathrm{x}}$ & $N$ & $S D$ \\
\hline big city & $12.39^{*} \pm 0.18$ & 39 & 1.14 \\
small town & $13.10 \pm 0.42$ & 11 & 1.40 \\
village & $13.21^{*} \pm 0.25$ & 23 & 1.18 \\
\hline * Significant difference between categories $(F=3.75$ \\
$p<0.05)$
\end{tabular}

Girls' puberty was sooner in fewchildren families (one or two children in the family) than in multi-children ones (three and more children in the family). The difference, though statistically insignificant, is nearly 6 months (Table 7).

Table 7. Age of menarche depending on the number of children in family

\begin{tabular}{lccc}
\hline $\begin{array}{l}\text { Number of } \\
\text { children in family }\end{array}$ & $\overline{\mathrm{x}}$ & $N$ & $S D$ \\
\hline one or two & $12.52 \pm 0.19$ & 36 & 1.13 \\
three or more & $12.98 \pm 0.23$ & 37 & 1.38 \\
\hline
\end{tabular}

Difference between categories insignificant $(t=1.56$; $p>0.05)$

The differentiation of menarche age depending on parents' education in the analyzed material was only revealed (insignificantly) when considering the mother's educational status (Table 8). The higher the mothers' educational level, the sooner the age of their daughters' menarche.

Even though it was not possible to specify the nature of all the examined girls' families, the family irregularities, despite a small number of questionnaires, seem to delay the girls' puberty rate (Table 9). 
Table 8. Girls' age of menarche depending on the mother's educational level

\begin{tabular}{lccc}
\hline $\begin{array}{l}\text { Mother's } \\
\text { education }\end{array}$ & $\bar{x}$ & $N$ & $S D$ \\
\hline $\begin{array}{l}\text { university or } \\
\text { secondary }\end{array}$ & $12.58 \pm 0.25$ & 25 & 1.23 \\
$\begin{array}{l}\text { vocational or } \\
\text { elementary }\end{array}$ & $12.90 \pm 0.22$ & 39 & 1.38 \\
\hline
\end{tabular}

Difference between categories insignificant $(t=0.94$; $p>0.05$ )

Table 9. Age of menarche depending on regularities in families of examined girls

\begin{tabular}{lccc}
\hline Nature of family & $\overline{\mathrm{x}}$ & $N$ & $S D$ \\
\hline normal & $12.74 \pm 0.27$ & 20 & 1.21 \\
irregular & $13.08 \pm 0.26$ & 23 & 1.26 \\
\hline
\end{tabular}

Difference between categories insignificant $(t=0.90$; $p>0.05$ )

Summing up, the age of menarche of schoolgirls of both centers was differentiated most considerably by the etiology of the sight organ disease (including premature birth) and the urban factor. The disease etiology and the urban factor turned out to be dependent factors $\left(\chi^{2}=4,61, v=4, p<0,05\right)$ in the examined material. The variance analysis in the double classification (the disease etiology and the size of place of origin) indicated the disease etiology as a factor considerably influencing $(p<0,05)$ the beginning of puberty in girls with sight defects.

The age of pubescence of girls with sight defects $(12,75)$ turned out to be nearly 5 months sooner than the one obtained for Wrockaw schoolgirls of the comparative group (13,16 years of age, HULANICKA et al. [1990]). Even though my research was conducted 8 years later than the examinations of the comparative group, it does not justify the significant (even considering the secular trend) acceleration of sexual puberty age in girls with sight deficiency, the more so as the puberty age acceleration in Poland has been reduced or even inhibited in the last two tens of years [BIELICKI \& HULANICKA 1998]. This situation is not explained by the social composition of both groups, either. The majority of girls with sight defects come from big cities admittedly (as in the comparative group), still high percentage of them come from multi-children families, and in $2 / 3$ cases their parents represent low level of education (elementary or vocational education).

The group accepted as a point of reference is quite different in terms of environmental conditions. This group consists of children and teenagers from the urban agglomeration of Wrocław, out of which $80 \%$ is brought up in one- or twochildren families, and over $2 / 3$ of mothers and of fathers have at least high education [HULANICKA et al. 1990]. It can be concluded from the above information that the social composition of the group represented by the girls with sight deficit is not responsible for their sooner first menstruation age, and quite on the contrary (considering what we know at present about the relationship between the menarche age and socio-economic environment in which children are brought up [MILICER 1968, ZACHARIAS \& WURTMAN 1969, KOLASA 1980, ŁASKA-MIERZEJEWSKA 1983, WALISZKO et al. 1987, WALISZKO 1988, CHARZEWSKI et al. 1991, HULANICKA et al. 1994, ROGOWSKA 1996]).

However, we may try to explain the cause of sooner pubescence of the examined girls with sight defects in terms of hormonal activity basing on our present knowledge of pubescence and the role of the endocrine system in this process. 
Well known and described changes of genitals, shape and body size take place during pubescence as well as the development of secondary sex character. Pubescence is a moderately harmonious process and significant deviations from the correct sequence of events should lead to suspecting pathology [BROWN et al. 1995].

The endocrine system is a factor initiating and controlling pubertal processes. The changes taking place within the system during this period concern [METERA \& ROMER 1997, ROMER 1997]:

- axis of hypothalamus - hypophysis gonads (causing gonadarche, that is somatic changes depending on the increase of sex steroids secretion by gonads);

- axis of hypothalamus - hypophysis adrenergic reticular layer (causing adrenarche, that is somatic changes caused by the increased secretion of adrenergic steroids);

- axis regulating secretion and action of growth hormone and growth factors (causing pubertal spurt of body growth).

An increase of pulsating secretion of luliberine $(\mathrm{Gn}-\mathrm{RH})$, that is a neurohormone stimulating the release of hypophysial gonadotropins takes place during pubescence. Apart from the night pulsating release, daily pulses also appear during this time, which leads to the pubertal full bloom, menarche and ovulation [STIRLING \& KELNAR 1993]. Gn-RH secretion is influenced, among others, by: suprathalamic centers, epiphysis and stimuli originating in the outer environment. As a result, first symptoms of gonadarche in girls are: the development of mammary glands and the increase of growth tempo [METERA \& ROMER 1997].
Premature sexual pubescence might be caused by sooner increase of hypothalamus-hypophysis-gonad axis activity (the so-called precocious proper puberty, central or Gn-RH dependent) or by the increase of steroid concentration in blood not preceded by the increase of Gn-RH and hypothalamic gonadotropin secretion (the so-called precocious puberty Gn$\mathrm{RH}$ - independent or false). The latter type of precocious puberty appears far more seldom than the former; its course is not harmonious since hormonal changes do not occur in a correct way [ROMER 1997; SKAŁBA 1998]. Central precocious puberty appears 4-10 times more frequently in girls (because of the lower threshold of gonadotropin secretion found in girls) than in boys and happens usually at approximately 6-7 year of age [METERA \& ROMER 1997]. The endocrine symptoms and the sequence of secondary sex characters are the same as during pubescence occurring at its normal age. No dangerous causes of this precocious puberty can be found in over $80 \%$ of girls [BROWN et al. 1995].

In the examined material no case of such early pubescence among the girls with sight deficit was found - menarche age of the earliest maturing of them was 9 years of age. Also, no information was gathered as to any special disorders in the pubescence course of the examined girls. In spite of this, I decided to investigate more closely the causes of the central precocious sexual puberty mentioned by clinicists. They are as follows: increased intracranial pressure, infections of central nervous system, perinatal traumas, developmental defects, arachnoid cysts, head injuries during childhood, skull irradiation, intracranial pathologies (neoplasms - more frequent in boys), idio- 
pathic causes [BROWN et al. 1995; METERA \& ROMER 1997].

Several of the above mentioned factors causing precocious puberty in children were also noted among the examined children with sight defects. They included head injuries during childhood $(N=11)$, cerebral neoplasms $(N=13)$ with related skull $\mathrm{x}$-rays and irradiations as well as perinatal traumas $(N=5)$. Therefore, one might suspect that they might have influenced the puberty age of the examined girls. The earliest pubescent girls among all with sight defects in the examined material were the ones born prematurely. Despite their small number, their menarche age appeared to be as long as one year sooner than in the remaining girls (Table 4). This result is consistent with ZACHARIAS \& WURTMAN [1964] report of sooner puberty of prematurely born girls among those with sight defects.

Causes of premature births and further physical development of those children (especially the phenomenon of compensation in somatic characteristics, that is the catch-up growth in relation to the children born in due time) constitute the subject of research and many publications [MISIAK 1990, KITCHEN et al. 1992, STĘPIŃSKI 1993, ORKWISZEWSKA \& GŁADYKOWSKA-RZECZYCKA 1994, ŁUCZAK 1996, SZULC \& CHAZAN 1997]; however, our knowledge of puberty age of prematurely born girls is very limited. ZACHARIAS \& WURTMAN [1964] were precursors of research in the field of puberty age of the girls with sight defects. They obtained results indicating sooner menarche age of blind girls in comparison to their seeing peers. The scientists' explanation of the research results was that the light stimulus is likely to influ- ence the activation of the neuroendocrine axis even in individuals with no light perception, but their lack of retina reaction to this stimulus probably disturbs in some way the organism equilibrium, which might result in a sooner menarche age in case of blind girls. This research was the first one attempting to find relation: light stimulus $\rightarrow$ retina $\rightarrow$ female ovary. Also BUDAY [1981], LUCZAK [1992], and BUDAY \& KAPOSI [1995] report sooner menarche age of blind girls in comparison to the seeing ones. There is a certain regularity in the above mentioned authors' research - the greater the sight impairment, the sooner the menarche age, i.e. blind girls enter puberty first, then blind girls with perception of light, and then the ones with amblyopia. This regularity is also confirmed by my research. Blind girls menstruated 6 months before the ones with sight impairment; the difference between both groups of girls appeared statistically insignificant, most probably as a result of the small number of girls with sight deficit (Table 2). There are, however, reports in the literature that no differences were observed between the puberty age of the girls with sight deficit of various degree, living in similar social environment conditions [THOMAS \& PIZZARELLO 1967, GUAZZELLI et al. 1979, BUDAY 1981].

Though the authors of the research works on puberty age in girls with sight deficit agree that there exists a relation between the sooner menarche age of these girls and the endocrine epiphysis activity [BUDAY 1981, LUCZAK 1992]. Recent research of secretory activity of epiphysis demonstrated that even in some blind patients, lacking light perception (but with retained circadian light and 
darkness rhythm) the inhibition of melatonine secretion occurs under the influence of their exposition to very bright light [CHEISLER et al. 1995]. The authors of this research believe that there are two basically different systems of light perception in humans. The first system is far more sensitive to light stimuli, and the light stimulus passes through a number of structures on its way to sight centers of cerebral cortex: light stimulus $\rightarrow$ retina $\rightarrow$ optic nerves $\rightarrow$ optic nerves' chiasm $\rightarrow$ optic tracts $\rightarrow$ lateral geniculate body $\rightarrow$ optic radiation $\rightarrow$ optic cortex. The other system, far less sensitive to light impulses in the seeing individuals, is a system in which light stimulus is carried from retina to hypothalamus, and precisely to suprachiasmatic nucleus. From there the light stimulus passes through postganglionic adrenergic fibers to epiphysis causing the inhibition of melatonine secretion [CHEISLER et al. 1995].

Thus, it seems that in blind individuals with a retained circadian rhythm, the latter light perception system has a special significance. The inhibition of melatonine secretion under the influence of light impulse originating in the outer environment, even in individuals lacking light perception, allows as a result for the acceleration of puberty processes [BELLASTELLA et al. 1995].

In my opinion, the earlier menarche age of the examined girls with the sight deficit might be explained in view of the factors causing the acceleration of puberty mentioned by clinicists, such as neoplasms, injuries and irradiations of the central nervous system, and especially the theory of existence of two separate light perception systems in humans presented above.

\section{Conclusions}

The following conclusions have been reached:

(1) Sooner puberty age of the examined girls with sight defects in comparison to the seeing girls:

- cannot be the effect of the secular trend exclusively;

- also, it cannot be explained by social structure of the examined group of girls in relation to the system of reference;

- it might be caused by (relatively numerous among the examined girls) a group of prematurely born girls, entering puberty a whole year sooner than the ones born in due time.

(2) It seems that the main cause of sooner puberty of the girls with sight organ diseases shall be seen in the disturbed (by their disability) activity of the neurohormonal system, and particularly in the secretory activity of epiphysis.

\section{References}

Bellastella A., A.A. Sinisi, T. Criscuolo, A. De Bellis, C. Carella, S. Ioro, F. Parlato, T. Venditto, G. PisAno, 1995, Melatonin and the pituitary-thyroid status in blind adults: a possible resetting after puberty, Clinical Endocrinology, 43, 707-711

BieliCKI T., B. HUlaNiCKA, 1998, Secular trend in stature and age at menarche in Poland [in:] Secular Growth Changes in Europe, Bodzsar B.E., C. Susanne (ed.), Eötvös Univ. Press, Budapest, pp. 263-279

Brown D.C., H.F. Stirling, C.J.H. Kelnar, 1995, Przedwczesne pokwitanie, Aktualności Pediatryczne, 4, 58-62

BUDAY J., 1981, Age at menarche in girls with sensory deprivation, Acta Medica Auxologica, 13, 131-139

BUDAY J., I. KAPOSI, 1995, Body development and physique of visually impaired children, Pro- 
ceedings of the $7^{\text {th }}$ Tartu International Anthropological Conference 29 May-2 June, Tartu

CHARZEWSKI J., T. ŁASKA-MiERZEJEWSKA, H. PiechaczeK, L. LuKaszewsKa, 1991, Wiek menarche dziewczat warszawskich 1976-1986, Wychowanie Fizyczne i Sport, 35, 15-29

Cheisler C.A., T.L. Shanahan, E.B. Klerman, H. Martens, D.J. BRotman, J.S. Emens, T. KLeIN, J.F. Rizzo, 1995, Supression of melatonin secretion in some blind patients by exposure to bright light, The New England J. Med., 332, 6-11

Guazzelli R., M. Piazzini, C. Conti, E. Montali, I. InZITARI, 1979, Eta del menarca nelle non vendeti dalla prima infanzia, Acta Med. Auxol., 11, 45-51

Hulanicka B., Cz. Brajczewski, W. JedlińsKa, T. SŁawiŃSKA, A. WALISZKO, 1990, Duże miasto - Małe miasto - Wieś. Różnice $w$ rozwoju fizycznym dzieci $w$ Polsce, Monografie Zakładu Antropologii PAN, Wrocław

Hulanicka B., E. Kolasa, A. WaliszKo, 1994, Dziewczęta z Górnego Ślaska, Monografie Zakładu Antropologii PAN, 11, Wrocław

Kitchen W.H., L.W. Doyle, G.W. Ford, C. Callanan, 1992, Very low weight and growth to age 8 years, Am. J. Diseas. Child., 146, 40-45

KolASA E., 1980, Wiek menarchy a budowa fizyczna studentek wrocławskich $w$ zależności od warunków środowiskowych, Materiały i Prace Antrop., 99, 3-62

ŁASKA-MieRZEJEWSKA T., 1983, Wptyw społecznego zróżnicowania ludności wiejskiej na wiek menarchy $i$ jego trend sekularny, Materiały i Prace Antrop., 103, 21-45

ŁUCZAK E., 1992, Wybrane uwarunkowania rozwoju somatycznego uczniów $w$ wieku 7-19 lat z wada wzroku, [in:] Biologia Populacji Ludzkich Wspótczesnych i Pradziejowych, WSP Słupsk, pp. 241-250

ŁUCZAK E., 1996, Rozwój fizyczny uczniów z porodów wcześniaczych w wieku 7-19 lat, Przegląd Antropologiczny, 59, 121-125

Metera M., T.E. Romer, 1997, Zasady rozpoznawania $i$ leczenia przedwczesnego dojrzewania płciowego, Klinika Pediatryczna, 5, 239-246
Milicer H., 1968, Wiek menarchy dziewczat wroctawskich w 1966 r. w świetle czynników środowiska społecznego, Materiały i Prace Antrop., 76, 25-60

MisIAK K., 1990, Epidemiologia wcześniactwa $i$ wad rozwojowych u noworodków matek zamieszkatych na terenie skażeń przemysłowych huty miedzi Legnica, Praca doktorska, Akademia Medyczna we Wrocławiu

ORKWISZEWSKA A., J. GŁADYKOWSKA-RZECZYCKA, 1994, Częstość urodzeń i stan rozwoju noworodków przedwcześnie urodzonych z masq ciała poniżej $2500 \mathrm{~g} w$ rejonie Gdańska, Przegląd Antropologiczny, 57, 33-39

RogowsKa E., 1996, Środowiskowe uwarunkowania wieku menarche, Zmienność Biologiczna Człowieka, 3, 151-160

ROMER T.E., 1997, Rola hormonów w procesie wzrastania, Klinika Pediatryczna, 5, 190-193

SkatbA P., 1998, Endokrynologia kliniczna, PZWL, Warszawa

STĘPIŃSKI W., 1993, Przyczyny porodów przedwczesnych $u$ kobiet $z$ Wroclawia $i$ woj. wroctawskiego, Praca doktorska, Akademia Medyczna we Wrocławiu

Stirling H.F., C.J.H. Kelnar, 1993, Pokwitanie, Aktualności Pediatryczne, 2, 166-173

Szulc E., B. Chazan, 1997, Poród przedwczesny. Prewencja matej masy urodzeniowej noworodków, Medycyna Wieku Rozwojowego, 1, 569-576

Thomas J.B., D.J. Pizarello, 1967, Blindness, biologic rhythms, and menarche, Obstet. Gynecol., 30, 507-509

WALISZKo A., 1988, The evolution of social gradients in menarcheal age in Wrockaw between 1966 and 1976, Studies in Physical Anthropology, 9, 3-15

WALiszKo A., B. HulanickA, T. Bielicki, 1987, Społeczne zróżnicowanie wieku menarchy dziewczat na Górnym Ślasku w 1981 roku, Przegląd Antropologiczny, 53, 51-75

ZACHARIAS L., R.J. WURTMAN, 1964, Blindness: Its relation to age of menarche, Science, 144, 1154-1155

Zacharias L., R.J. WURTMAn, 1969, Age at menarche. Genetic and environmental influences, The New England J. Med., 280, 869-875 


\section{Streszczenie}

Nieliczne prace dotyczące wieku pierwszej menstruacji dziewcząt ze schorzeniami narządu wzroku świadczą o wcześniejszym pokwitaniu tych dziewcząt niż ich normalnie widzących rówieśnic. Ponadto niektórzy autorzy postulują ważną rolę szyszynki w tym procesie.

Celem badań było ustalenie wieku pokwitania dziewcząt $\mathrm{z}$ wadami wzroku w zależności od stopnia upośledzenia widzenia, etiologii wady wzroku i wybranych zmiennych środowiska społeczno-ekonomicznego, a także próba wyjaśnienia tego zjawiska na podłożu endokrynologicznym.

Materiał stanowiło 130 dziewcząt w wieku od 6 do 20 lat, wychowanek Ośrodków Szkolno-Wychowawczych Dzieci Niedowidzących i Niewidomych we Wrocławiu i w Krakowie (tab. 1). Zmienność wieku pierwszej menstruacji badanych dziewcząt, określonego metodą retrospektywna, oceniano w zależności od: stopnia upośledzenia widzenia (tab. 3), etiologii wady wzroku (tab. 4), terminowości porodu, z którego pochodziła badana (tab. 5), wybranych czynników społeczno-ekonomicznych, takich jak pochodzenie, dzietność rodzin, poziom wykształcenia rodziców oraz ewentualne nieprawidłowości w rodzinach badanych dziewcząt (tab. 6-9).

Uzyskane wyniki wskazują, iż najwcześniej pokwitają dziewczęta niewidome z nabytymi schorzeniami narządu wzroku, zwłaszcza te, które urodziły się przedwcześnie. Wcześniejszy niż u normalnie widzących rówieśnic wiek menarche badanych dziewcząt $\mathrm{z}$ deficytem wzroku można wyjaśniać wymienianymi przez kilinicystów czynnikami powodującymi przyspieszenie pokwitania, takimi jak nowotwory, urazy i napromieniowania ośrodkowego układu nerwowego, a także poprzez teorię istnienia dwóch odrębnych systemów percepcji światła u człowieka. 